\title{
Pengaruh Asam Traneksamat Intravena terhadap Jumlah Perdarahan Intraoperatif dan Kebutuhan Transfusi pada Operasi Meningioma
}

\author{
Sigit Sutanto, Dewi Yulianti Bisri, Tatang Bisri \\ Departemen Anestesiologi dan Terapi Intensif Fakultas Kedokteran Universitas Padjadjaran/RSUP Dr. Hasan \\ Sadikin Bandung
}

\begin{abstract}
Abstrak
Latar Belakang dan Tujuan: Meningioma merupakan tumor otak yang berisiko tinggi terjadi perdarahan pada reseksi massa. Penelitian dengan rancangan double blind RCT dilakukan pada 40 subjek meningioma di RSUP Dr Hasan Sadikin Bandung dengan tujuan melihat pengaruh asam traneksamat (TXA) dalam mengurangi jumlah perdarahan intraoperatif dan kebutuhan transfusi.

Subjek dan Metode: Subjek penelitian dibagi dua kelompok, kelompok A diberikan asam traneksamat intravena $20 \mathrm{mg} / \mathrm{kg}$ dalam $\mathrm{NaCl}$ 0,9\% $100 \mathrm{~mL}$ dan kelompok B diberikan $\mathrm{NaCl}$ 0,9\% $100 \mathrm{~mL}$ sebelum insisi. Data hemodinamik, jumlah cairan, jumlah transfusi dan jumlah perdarahan intraoperatif dicatat per jam. Dilakukan pemeriksaan kadar $\mathrm{Hb}, \mathrm{Ht}$ dan faktor pembekuan pascaoperasi dan 24 jam pascaoperasi. Data hasil penelitian diuji secara statistik menggunakan uji t tidak berpasangan dan uji Mann-Whitney.

Hasil: Perdarahan intraoperatif $(1008,51 \pm 327,192$ vs $1347 \pm 539,120 \mathrm{ml} ; \mathrm{p}=0,021)$, kebutuhan pada transfusi packed red cell (PRC) intraoperatif $(89,30 \pm 152,970 \mathrm{ml}$ vs $306,85 \pm 224,631 \mathrm{ml}$; $=0,003)$, kebutuhan transfusi PRC 24 jam pasca operasi $(88,50 \pm 153,014 \mathrm{ml}$ vs 212,00 $\pm 212,505 \mathrm{ml} ; \mathrm{p}=0,028)$ pada kelompok A secara signifikan lebih kecil dari kelompok B.

Simpulan: Asam traneksamat $20 \mathrm{mg} / \mathrm{kg}$ yang diberikan intravena sebelum insisi dapat mengurangi jumlah perdarahan intraoperatif dan kebutuhan transfusi pada operasi tumor otak suspek meningioma.
\end{abstract}

Kata kunci: Asam traneksamat, bedah saraf, meningioma, perdarahan, intraoperatif, packed red cell, transfusi

JNI 2019;8 (1): 8-16

\section{Effects of Intravenous Tranexamic Acid on Blood Loss and Transfusion Requirements in Tumor Removal Surgery of Suspected Meningioma}

\begin{abstract}
Background and objective: Meningiomas are highly vascular brain neoplasms that often associated with substantial blood loss. This experimental, double-blind RCT conducted in Dr. Hasan Sadikin Hospital, enrolled 40 subjects with intracranial meningioma underwent surgical excision. The objective of this study is to see the effect of tranexamic acid (TXA) in reducing bleeding and transfusion requirements

Subjects and Method: Subjects divided into two groups, group A received tranexamic acid $20 \mathrm{mg} / \mathrm{kg}$ body weight in $100 \mathrm{~mL}$ normal saline, and group B received $100 \mathrm{~mL}$ normal saline before incision. Intraoperative hemodynamics, amount of fluid, transfusions, and blood loss were recorded hourly. Hemoglobin, hematocrit, and coagulation factors measured in postoperative, and subjects were followed up for the first 24 hours to record transfusion requirements and laboratorium work up. We analyzed the data using t-test and Mann-Whitney test.

Results: Intraoperative blood loss $(1008,51 \pm 327,192$ vs $1347 \pm 539,120 \mathrm{ml} ; \mathrm{p}=0,021)$, intraoperative packed red cell (PRC) transfusion requirement $(89,30 \pm 152,970 \mathrm{ml}$ vs $306,85 \pm 224,631 \mathrm{ml}, \mathrm{p}=0,003), \mathrm{PRC}$ transfusion requirement in first24hourspostoperative $(88,50 \pm 153,014 \mathrm{mlvs} 212,00 \pm 212,505 \mathrm{ml}, \mathrm{p}=0,028)$ ingroupAsignificantlylessthangroup $B$ Conclusions: Administration of intravenous tranexamic acid $20 \mathrm{mg} / \mathrm{kg}$ before incision can reduce intraoperative blood loss and transfusion requirement in patients underwent surgical excision of meningioma
\end{abstract}

Key words: Intraoperative blood loss, meningioma, neurosurgery, packed red cell, tranexamic acid, transfusion

JNI 2019;8 (1): 8-16 
Pengaruh Asam Traneksamat Intravena Terhadap Jumlah

\section{Pendahuluan}

Tumor otak adalah kumpulan sel patologis pada otak yang bermultiplikasi dan dapat menyebabkan kerusakan pada jaringan sekitarnya dan organorgan terkait. Central Brain Tumor Registry of the United States (CBTRUS), pada tahun 2007 hingga 2011 melaporkan angka kejadian tumor supratentorial adalah lebih dari $80 \%$ dari total tumor otak. Tumor terbanyak adalah jenis meningioma (36\%), diikuti glioblastoma $(15 \%){ }^{1-}$

3 Gambaran karakteristik tumor otak di RS Dr. Hasan Sadikin Bandung pada tahun 2012-2013 dilaporkan terbanyak adalah tumor supratentorial jenis meningioma sebanyak 111 kasus $(66,07 \%)$ dari 168 kasus seluruh jenis tumor otak, sedangkan gambaran letak meningioma supratentorial terbanyak adalah di sisi kiri sebanyak 62 kasus $(36,90 \%){ }^{4}$ Meningioma merupakan tumor otak yang kaya akan pembuluh darah dan seringkali mengalami banyak perdarahan dalam reseksi massa. ${ }^{5}$ Terapi definitif meningioma adalah reseksi massa, sedangkan modalitas terapi lain mencakup kemoterapi dan radioterapi. Perdarahan intraoperatif merupakan salah satu komplikasi utama pada operasi tumor otak dan berhubungan langsung dengan morbiditas dan mortalitas pasien. ${ }^{6}$ Perdarahan intraoperatif seringkali diganti dengan cairan kristaloid, koloid, serta transfusi produk darah dalam jumlah besar. Transfusi produk darah alogenik memiliki risiko efek samping dari mulai dari asidosis, toksisitas sitrat, hiperkalemia, hipokalsemia, hingga reaksi anafilaktik berat, transfussion related acute lung injury (TRALI), infeksi, overload sirkulasi, hingga imunosupresi. Pemberian cairan dalam jumlah besar juga diketahui dapat mengganggu faktor koagulasi sehingga memperberat perdarahan. ${ }^{7,8}$

Keputusan memberikan transfusi selama pembedahan memberikan keuntungan seperti memperbaiki kapasitas pengangkutan oksigen namun juga memiliki risiko infeksi, hemolisis, cedera paru serta imunosupresi. Studi in vitro menunjukkan delivery oxygen $\left(\mathrm{DO}_{2}\right)$ ke jaringan optimal dalam kadar hematokrit $(\mathrm{Ht})$ sekitar 30\%. Kadar hemoglobin $(\mathrm{Hb})$ optimal pada pasien bedah saraf dengan gangguan neurologis dipertahankan pada kisaran of 9-10 $\mathrm{g} / \mathrm{dl}$ dengan tetap mempertimbangkan risiko dan manfaat secara individual per kasus. Untuk mengatasi masalah yang berkaitan dengan pemberian transfusi masif, beberapa strategi telah dilakukan untuk mengurangi jumlah cairan dan transfusi intraoperatif, antara lain memperbaiki massa eritrosit dengan eritropoietin preoperatif, blood tapping autolog preoperatif, hemodilusi normovolemik, serta teknik hipotensi terkendali. Strategi-strategi diatas bukan tanpa komplikasi dan tidak semua dapat dikerjakan karena ketersediaan dan cost-effectiveness, mendorong ditelitinya efikasi dari agen-agen hemostatik seperti asam aminokaproat, asam traneksamat, desmopressin, aprotinin, serta estrogen terkonjugasi. ${ }^{9,10}$ Asam traneksamat (trans-4-amino methyl cyclohexane carboxylic acid) merupakan golongan antifibrinolitik yang bekerja menghambat aktivasi plasminogen menjadi plasmin pada pembekuan darah.

Karena plasmin berfungsi mendegradasi fibrin, maka asam traneksamat bekerja menghambat degradasi fibrin, yang berujung pada meningkatnya aktivitas pembekuan darah. ${ }^{11-13}$ Asam traneksamat berhasil digunakan pada pembedahan dengan risiko perdarahan yang tinggi seperti operasi jantung, pembuluh darah, bedah saraf dasar tengkorak (skullbase), ortopedi, tulang belakang, serta obstetri ginekologi. ${ }^{11,14-16}$

Pada pasien trauma, pemberian asam traneksamat secara dini menurunkan angka mortalitas secara signifikan. ${ }^{17}$ Penelitian di Arab Saudi tahun 2015 terhadap pasien yang menjalani kraniotomi pengangkatan tumor otak membandingkan pemberian asam traneksamat $10 \mathrm{mg} / \mathrm{kg}$ bolus intravena diikuti $1 \mathrm{mg} / \mathrm{kg} / \mathrm{jam}$ dengan plasebo. Hasil dari penelitian ini menunjukkan jumlah perdarahan yang secara signifikan lebih rendah pada kelompok asam traneksamat dibandingkan kelompok plasebo namun tidak didapatkan perbedaan jumlah kebutuhan transfusi. ${ }^{18}$

Penelitian tahun 2016 di India terhadap pasien yang menjalani kraniotomi pengangkatan tumor meningioma elektif membandingkan jumlah perdarahan intraoperatif dan kebutuhan 
transfusi antara kelompok yang diberikan asam traneksamat $20 \mathrm{mg} / \mathrm{kg}$ selama 20 menit sebelum insisi diikuti $1 \mathrm{mg} / \mathrm{kg} / \mathrm{jam}$ hingga selesai operasi dibandingkan dengan plasebo. Kelompok asam traneksamat secara signifikan lebih sedikit jumlah perdarahan intraoperatif dan kebutuhan transfusi dibandingkan kelompok plasebo. ${ }^{19}$

\section{Subjek dan Metode}

Tipe penelitian ini adalah eksperimental, dengan melakukan uji klinis rancangan acak klinis terkontrol, tersamar ganda (double blind randomized controlled trial) yang dilakukan terhadap 40 subjek penelitian dengan tumor otak suspek meningioma di RSUP Dr. Hasan Sadikin, Bandung yang memenuhi kriteria inklusi. Pengambilan sampel pasien dilakukan secara consecutive sampling dan alokasi subjek ke dalam salah satu kelompok dilakukan dengan cara acak sederhana (menggunakan amplop tertutup).

Kriteria inklusi adalah pasien dengan tumor otak suspek meningioma yang menjalani kraniotomi pengangkatan tumor elektif, berusia 18-65 tahun dengan status fisik ASA (American's Society of Anesthesiologist) I-II. Kriteria eksklusi meliputi riwayat kejadian tromboemboli, pasien dengan koagulopati atau dalam terapi antikoagulan, gangguan fungsi ginjal dan fungsi hati, riwayat alergi asam traneksamat dan obat-obat lain yang digunakan dalam penelitian, operasi
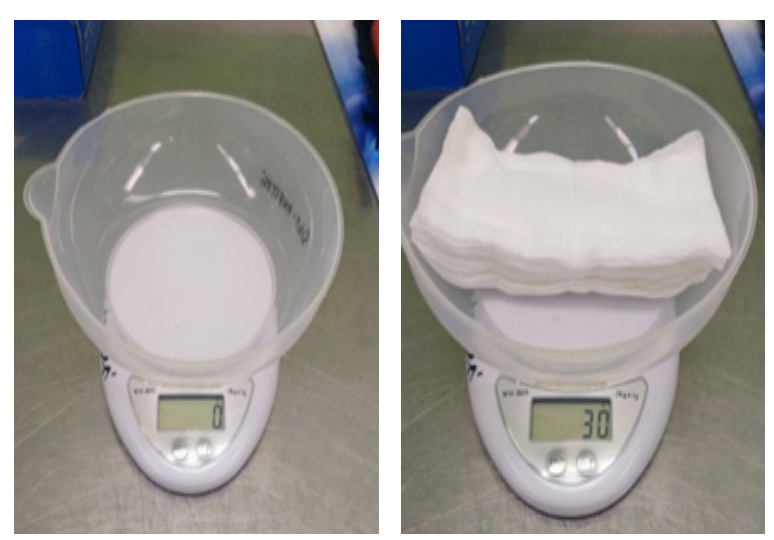

Gambar 1. Berat Kassa yang digunakan

Keterangan: 1) Alat timbang digital yang telah dikalibrasi menunjukkan angka 0 ; 2) Kassa yang digunakan pada operasi bedah saraf sebanyak 10 buah, menunjukkan angka 30 gram (berat 1 buah kassa $\approx 3$ gram) ulangan karena tumor residif, tumor intrakranial merupakan metastasis, telah menjalani embolisasi preoperasi serta dalam keadaan hamil atau dalam masa nifas (6 minggu pasca persalinan). Kriteria pengeluaran bila terjadi morbiditas di meja operasi, misalkan terkena sinus yang menyebabkan perdarahan masif dan bila terjadi mortalitas di meja operasi.

Penelitian dikerjakan setelah mendapat persetujuan dari Komite Etik Penelitian RSUP dr. Hasan Sadikin/ Fakultas Kedokteran Universitas Padjadjaran. Pasien dibagi dalam dua kelompok : Kelompok A (asam traneksamat) dan Kelompok B (kontrol). Dilakukan pemasangan jalur intravena dengan canula vena no. 18 (®Introcan - B Braun), alat pantau EKG, tekanan darah invasif maupun non-invasif, dan pulse oksimetri Lifescope 14 Nihon Kohden. Pemasangan alat lain seperti kateter vena sentral dan arterial line disesuaikan dengan penilaian dari tim anestesi. Pasien diposisikan sesuai posisi yang diinginkan, kemudian dicatat data dasar tanda vital. Pasien dilakukan induksi anestesi umum dengan ventilasi mekanik. Tiga puluh menit sebelum dilakukan insisi, kelompok A diberikan asam traneksamat $20 \mathrm{mg} / \mathrm{kg}$ berat badan yang dilarutkan dalam $\mathrm{NaCl}$ 0.9\% $100 \mathrm{ml}$ selama 5-10 menit, kelompok B diberikan $\mathrm{NaCl} \quad 0.9 \% 100 \mathrm{ml}$ selama 5-10 menit. Rerata mean arterial pressure (MAP) dan laju nadi dicatat per jam. Jumlah perkiraan perdarahan dicatat tiap jam. Tidak dilakukan teknik hipotensi terkendali selama operasi. Tidak diberikan dosis ulangan asam traneksamat selama operasi. Jumlah perkiraan perdarahan dihitung dari tangki suction (selisih jumlah cairan di tangki dikurangi jumlah cairan bilas), jumlah kassa yang berdarah, serta yang terdapat di lapangan operasi dan ditampung ke baskom penampungan yang dialasi plastik. Kassa yang digunakan ditimbang sebelumnya dan ditimbang kembali setelah dipenuhi darah. Diketahui berat satu kassa $10 \times 10 \mathrm{~cm}$ yang digunakan pada operasi bedah saraf adalah 3 gram (gambar 3.1 keterangan 1: berat 10 kassa, keterangan2: berat 20 kassa). Bila ditetapkan berat jenis darah adalah 1,060 $\mathrm{mg} / \mathrm{ml}$, maka jumlah darah pada penimbangan adalah 20 : jumlah darah $(\mathrm{ml})=$ [berat kassa berdarah (g) - (jumlah kassa x 3 gram)] x 1,060. 
Pengaruh Asam Traneksamat Intravena Terhadap Jumlah Perdarahan Intraoperatif dan Kebutuhan Transfusi pada Operasi

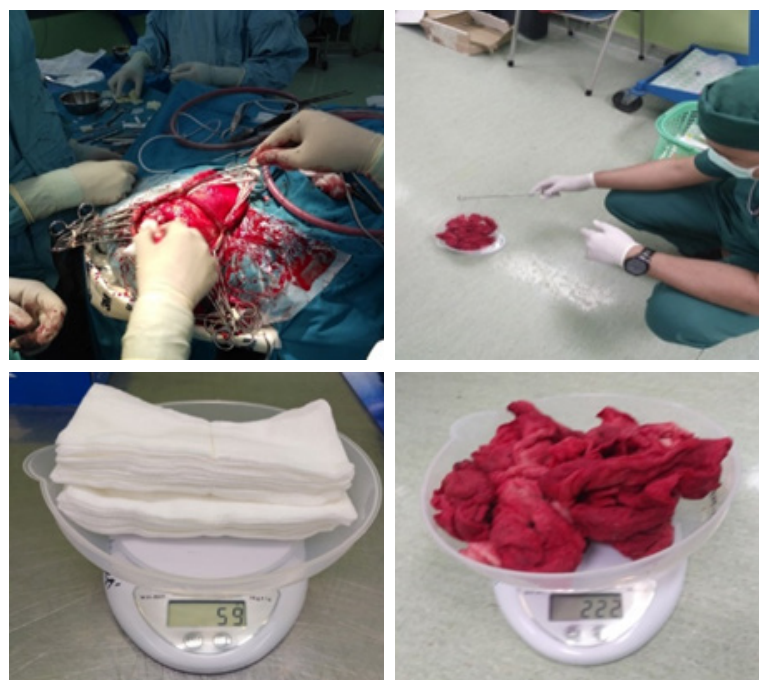

Gambar 2. Observasi Perdarahan Intraoperatif

Keterangan: 1) Lapangan operasi menggunakan plastik steril 3M yang melekat melapisi kulit, kemudian sisinya dibentuk agar dapat menampung perdarahan sehingga mudah dilakukan suctioning; 2) Pengumpulan kassa yang menyerap darah. Kassa yang hanya menyerap cairan bilas tidak diikutkan ditimbang; 3) Kassa sebelum dilakukan operasi sejumlah 20 buah dengan berat masing-masing $\approx 3$ gram; 4) Kassa sebanyak 20 buah yang telah menyerap darah, dengan berat 222 gram. Jumlah darah $(\mathrm{ml})=[$ Berat kassa berdarah (g) - (jumlah kassa x 3 gram)] x 1,060, maka jumlah darah pada kassa ini $=(222-59) \times 1,060=172,78$ $\mathrm{ml}$.

Apabila perdarahan melebihi allowable blood loss yang telah dihitung sebelumnya dan diambil keputusan untuk melakukan transfusi, maka dicatat jenis produk darah dan jumlah pemberian transfusi. Setelah operasi selesai, dilakukan pemeriksaan laboratorium $\mathrm{Hb}, \mathrm{Ht}$, trombosit dan PT/INR/aPTT. Selama 24 jam, dicatat kembali jumlah transfusi dan jenis produk darah yang diberikan. Pemeriksaan $\mathrm{Hb}, \mathrm{Ht}$, trombosit dan PT/INR/aPTT dilakukan kembali 24 jam pasca operasi.

\section{Hasil}

Subjek penelitian berjumlah 40 orang dibagi menjadi dua kelompok dengan karakteristik umum yang dijelaskan pada tabel 1. Rerata usia kelompok A adalah $47.40( \pm 5.861)$ tahun dan kelompok B 44.20 \pm 6.932 tahun. Jenis kelamin terbanyak adalah perempuan sebanyak 36 subjek $(90 \%)$, sedangkan laki-laki hanya 4 subjek (10\%). Seluruh subjek dikategorikan status fisik
ASA II. Ukuran tumor pada kelompok A ratarata $33.75(15.30-185.63) \mathrm{cm} 3$ dan kelompok $\mathrm{B}$ $28.00(13.50-225.00) \mathrm{cm} 3$. Hasil uji statistik pada kedua kelompok penelitian diperoleh informasi nilai $\mathrm{p}$ pada variabel umur, berat badan, ukuran tumor, tanda vital dasar, nilai $\mathrm{Hb}, \mathrm{Ht}$, dan faktor pembekuan preoperatif lebih besar dari 0.05 (nilai $\mathrm{p}>0.05$ ) yang berarti kedua kelompok dianggap homogen dan layak dilakukan uji statistik lebih lanjut.

Tabel 2 menjelaskan estimasi perdarahan pada kelompok Arata-rata sebesar 1008,51 $\pm 327,192 \mathrm{ml}$ sedangkan kelompok B sebesar 1347,85 $\pm 539,120$ $\mathrm{ml}(\mathrm{p}=0,021)$. Median jumlah kristaloid yang digunakan sebesar $2000 \mathrm{ml}$ dengan kisaran 1250$2500 \mathrm{ml}$ pada kelompok A, dibandingkan 2500 $\mathrm{ml}$ dengan kisaran 1750-4000 ml pada kelompok B $(p=0,012)$. Lama operasi pada kelompok A rata-rata $313,50 \pm 85,672$ menit dibandingkan kelompok B $387 \pm 126,203$ menit $(\mathrm{p}=0,033)$. Lama anestesi pada kelompok A rata-rata $346,50 \pm 88,927$ menit dibandingkan kelompok $B$ rata-rata $421,50 \pm 128,933$ menit $(p=0,040)$. Jumlah pasien yang ditransfusi intraoperatif pada kelompok A sebesar 6 pasien (30\%), dan sebanyak 15 pasien $(75 \%)$ pada kelompok B $(p=0.004)$. Pada tabel 3, rata-rata penggunaan transfusi PRC intraoperatif kelompok A sebesar $89,30 \pm 159,970 \mathrm{ml}$ dibandingkan kelompok B $306,85 \pm 224,631 \mathrm{ml}(\mathrm{p}=0,003)$.

Pada kelompok A tidak terdapat pasien yang mendapatkan transfusi FFP intraoperatif

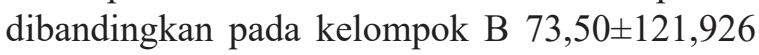
$\mathrm{ml}(\mathrm{p}=0,108)$. Pada kedua kelompok tidak terdapat pasien yang mendapatkan transfusi trombosit intraoperatif. Tabel 4 menjelaskan rata-rata kadar $\mathrm{Hb}$ pasca operasi kelompok A sebesar 11,01 $\pm 2,558 \mathrm{~g} / \mathrm{dl}$, pada kelompok B sebesar 9,31 $\pm 1,509 \mathrm{~g} / \mathrm{dl}(\mathrm{p}=0,005)$. Kadar Ht pasca operasi pada kelompok A sebesar $31,39 \pm 4,662 \%$ sedangkan pada kelompok B sebesar $27,92 \pm 4,678 \%(p=0,024)$. Sedangkan kadar trombosit, PT, INR dan aPTT pasca operasi pada kedua kelompok tidak menunjukkan perbedaan signifikan $(\mathrm{p}>0,05)$. Tabel 5 menjelaskan rerata kadar $\mathrm{Hb} 24$ jam pasca operasi kelompok A 10,92 $( \pm 1,012) \mathrm{g} / \mathrm{dl}$ sedangkan pada 
Tabel 1. Perbandingan karakteristik subjek penelitian +

\begin{tabular}{|c|c|c|c|}
\hline \multirow[b]{2}{*}{ Variabel } & \multicolumn{3}{|c|}{ Kelompok } \\
\hline & $\begin{array}{c}\text { A (Asam Traneksamat) } \\
\qquad \mathrm{N}=20\end{array}$ & $\begin{array}{c}\mathrm{B} \text { (Kontrol) } \\
\mathrm{N}=20\end{array}$ & Nilai $p$ \\
\hline Umur (tahun)* & $47,40( \pm 5,861)$ & $44,20 \pm 6,932$ & 0,123 \\
\hline Laki-laki & $1(5,0 \%)$ & $3(15,0 \%)$ & \\
\hline Perempuan & $19(95,0 \%)$ & $17(85,0 \%)$ & \\
\hline Berat Badan $(\mathrm{kg})^{*}$ & $57,25 \pm 8,967$ & $56,67 \pm 10,422$ & 0,853 \\
\hline ASA I & $0(0,0 \%)$ & $0(0,0 \%)$ & 1,000 \\
\hline ASA II & $20(100,0 \%)$ & $20(100,0 \%)$ & $1, .000$ \\
\hline \multicolumn{4}{|l|}{ Letak tumor } \\
\hline Sisi kanan & $7(35,0 \%)$ & $8(40,0 \%)$ & \\
\hline Sisi kiri & $11(55,0 \%)$ & $8(40,0 \%)$ & \\
\hline Sellar & $1(5,0 \%)$ & $1(5,0 \%)$ & \\
\hline Sisi tengah & $1(5,0 \%)$ & $1(5,0 \%)$ & \\
\hline Bilateral & $0(0,0 \%)$ & $1(5,0 \%)$ & \\
\hline Infratentorial & $0(0,0 \%)$ & $1(50 \%)$ & \\
\hline Ukuran tumor $(\mathrm{cm} 3) * *$ & $33,75(15,30-185,63)$ & $28,00(13,50-225,00)$ & 0,947 \\
\hline \multicolumn{4}{|l|}{ Midline shift (mm) } \\
\hline 0 & $8(40,0 \%)$ & $8(40,0 \%)$ & 0,123 \\
\hline$<5$ & $8(40,0 \%)$ & $3(15,0 \%)$ & \\
\hline$>5$ & $4(20,0 \%)$ & $9(45,0 \%)$ & \\
\hline \multicolumn{4}{|l|}{ Tanda vital baseline } \\
\hline MAP (mmHg) & $91,35 \pm 8,171$ & $88,1 \pm 11,317$ & 0,242 \\
\hline Laju nadi (x/menit) & $83,7 \pm 7,469$ & $82,75 \pm 6,656$ & 0,309 \\
\hline \multicolumn{4}{|l|}{ Lab preoperatif } \\
\hline $\mathrm{Hb}(\mathrm{g} / \mathrm{dl})^{*}$ & $13,82( \pm 0,878)$ & $12,98( \pm 1,277)$ & 0,121 \\
\hline $\mathrm{Ht}(\%)^{*}$ & $40,70( \pm 2,630)$ & $38,72( \pm 3,882)$ & 0,133 \\
\hline Trombosit (/ul)* & $321400,00( \pm 63974,83)$ & $299650,00( \pm 68329,13)$ & 0,429 \\
\hline PT (detik)* & $11,99( \pm 1,887)$ & $11,67( \pm 1,640)$ & 0,529 \\
\hline INR* & $0,94( \pm 0,045)$ & $0,96(0,048)$ & 0,132 \\
\hline aPTT (detik)* & $26,85( \pm 4,347)$ & $26,63( \pm 4,274)$ & 0,870 \\
\hline
\end{tabular}

kelompok B 10,50 $( \pm 0,722)$ g/dl $(\mathrm{p}=0,144)$. Jumlah pasien yang ditransfusi dalam 24 jam pasca operasi pada kelompok A sebanyak 6 pasien (30\%), sedangkan pada kelompok B sebanyak 13 pasien $(65 \%)$ dengan nilai $\mathrm{p}=0,027$. Rata-rata pemakaian transfusi PRC 24 jam pasca operasi pada kelompok A sebesar 88,50 $\pm 153,014$ ml sedangkan pada kelompok B sejumlah $212 \pm 212,505 \mathrm{ml}(\mathrm{p}=0,028)$. Pada gambar 2 MAP rerata kedua kelompok yang dicatat per jam selama operasi, rerata terendah pada kelompok A pada MAP 79,43 mmHg, sedangkan pada kelompok B rerata MAP terendah pada $74 \mathrm{mmHg}$. Gambar 4 menjelaskan jumlah perdarahan per jam pada kedua kelompok. Pada kelompok A puncak rerata jumlah perdarahan terjadi pada jam ke-3 (315,80 ml), sedangkan pada kelompok B rerata perdarahan terbanyak juga pada jam ke-3 sebesar 368, $85 \mathrm{ml}$. 
Tabel 2. Perbandingan Variabel Intraoperatif $\nmid$

\begin{tabular}{llll}
\hline Variabel & \multicolumn{1}{c}{ Kelompok } & & Nilai $\mathrm{p}$ \\
& $\mathrm{A}($ Asam Traneksamat & $\mathrm{B}($ Kontrol $)$ & \\
& $\mathrm{N}=20$ & $\mathrm{~N}=20$ & 0,021 \\
\hline Estimasi perdarahan $(\mathrm{ml})$ & $1008,51( \pm 327,192)$ & $1347,85( \pm 539,120)$ & 0,012 \\
Penggunaan kristaloid (ml)* & $2000,00(1250,00-2500,00)$ & $2500,00(1750,00-$ & 0,779 \\
& & $4000,00)$ & \\
Penggunaan koloid (ml)* & $387,50(0,00-1000,00)$ & & 0,004 \\
Jumlah pasien & & $450,00(0,00-1500,00)$ & 0,033 \\
ditransfusi** & $6(30 \%)$ & & 0,040 \\
Lama operasi (menit) & $313,50( \pm 85,672)$ & $15(75 \%)$ & $387,00( \pm 126,203)$ \\
Lama anestesi (menit) & $346,50( \pm 88,927)$ & $421,50( \pm 128,933)$ & \\
& & & \\
\hline
\end{tabular}

† Data dinyatakan dalam Mean (+SD) kecuali disebutkan lain, *Data dinyatakan dalam Median (minimal, maksimal), **Data dinyatakan dalam persen

Tabel 3. Perbandingan Kebutuhan Transfusi Intraoperatif $千$

\begin{tabular}{|c|c|c|c|}
\hline Variabel & $\begin{array}{c}\text { Kelompok } \\
\text { A (Asam Traneksamat) } \\
\mathrm{N}=20\end{array}$ & $\begin{array}{l}\mathrm{B} \text { (Kontrol) } \\
\mathrm{N}=20\end{array}$ & Nilai $\mathrm{p}$ \\
\hline \multicolumn{4}{|l|}{ Transfusi PRC intraoperatif } \\
\hline Volume PRC (ml) & $89,30( \pm 152,970)$ & $306,85( \pm 224,631)$ & 0,003 \\
\hline \multicolumn{4}{|l|}{ Transfusi FFP intraoperatif } \\
\hline Volume FFP (ml) & $0,00( \pm 0,00)$ & $73,50( \pm 121,926)$ & 0,108 \\
\hline $\begin{array}{l}\text { Transfusi trombosit intraoperatif } \\
\text { Volume trombosit }(\mathrm{ml})\end{array}$ & $0,00( \pm 0,00)$ & $0,00( \pm 0,00)$ & 1,000 \\
\hline
\end{tabular}

Tabel 4. Perbandingan Variabel Pascaoperasi $\uparrow$

\begin{tabular}{|c|c|c|c|}
\hline \multirow[t]{2}{*}{ Variabel } & \multicolumn{2}{|l|}{ Kelompok } & \multirow[t]{2}{*}{ Nilai $\mathrm{p}$} \\
\hline & $\begin{array}{c}\text { A (Asam Traneksamat) } \\
\mathrm{N}=20\end{array}$ & $\begin{array}{c}\mathrm{B} \text { (Kontrol) } \\
\mathrm{N}=20\end{array}$ & \\
\hline \multicolumn{4}{|c|}{ Parameter lab pasca operasi } \\
\hline $\mathrm{Hb}(\mathrm{g} / \mathrm{dl})$ & $11,01( \pm 2,558)$ & $9,31 \pm 1,509$ & 0,005 \\
\hline $\mathrm{Ht}(\%)$ & $31,39( \pm 4,662)$ & $27,92 \pm 4,678$ & 0,024 \\
\hline Trombosit & $244450,00( \pm 88419,142)$ & $208900,00( \pm 68732,816)$ & 0,164 \\
\hline$(1 \times 103)$ & $0,00( \pm 0,00)$ & $0,00( \pm 0,00)$ & 1,000 \\
\hline PT (detik) & $12,80( \pm 2,134)$ & $12,37( \pm 1,728)$ & 0,738 \\
\hline INR & $1,08( \pm 0,165)$ & $1,09( \pm 0,151)$ & 0,968 \\
\hline aPTT (detik) & $28,21( \pm 5,030)$ & $27,50( \pm 4,718)$ & 0,646 \\
\hline
\end{tabular}

+ Data dinyatakan dalam Mean (+SD) 
Tabel 5. Perbandingan Variabel 24 Jam Pasca Operasi

\begin{tabular}{|c|c|c|c|}
\hline \multirow[t]{2}{*}{ Variabel } & \multicolumn{2}{|l|}{ Kelompok } & \multirow[t]{2}{*}{ Nilai $p$} \\
\hline & $\begin{array}{c}\text { A (Asam Traneksamat) } \\
\mathrm{N}=20\end{array}$ & $\begin{array}{c}\text { B (Kontrol) } \\
\mathrm{N}=20\end{array}$ & \\
\hline \multicolumn{4}{|c|}{ Parameter lab pasca operasi } \\
\hline $\mathrm{Hb}(\mathrm{g} / \mathrm{dl})$ & $10,92( \pm 1,012)$ & $10,50( \pm 0,722)$ & 0,144 \\
\hline $\mathrm{Ht}(\%)$ & $32,52( \pm 2,763)$ & $31,40( \pm 2,255)$ & 0,091 \\
\hline Trombosit $(1 \times 103)$ & $233550,00( \pm 72383,099)$ & $240450,00( \pm 106321,496)$ & 0,718 \\
\hline PT (detik) & $12,51( \pm 1,515)$ & $12,65( \pm 1,634)$ & 0,773 \\
\hline INR & $1,057( \pm 0,926)$ & $1,08( \pm 0,109)$ & 0,841 \\
\hline aPTT (detik) & $28,70( \pm 4,340)$ & $27,95( \pm 4,814)$ & 0,529 \\
\hline Transfusi pasca operasi & $6(30 \%)$ & $13(65 \%)$ & 0,027 \\
\hline \multicolumn{4}{|l|}{ Jumlah pasien ditransfusi* } \\
\hline PRC (ml) & $88,50( \pm 153,014)$ & $212,00( \pm 212,505)$ & 0,028 \\
\hline FFP (ml) & $27,00( \pm 88,084)$ & $63,00( \pm 105,685)$ & 0,314 \\
\hline Trombosit (ml) & $0,00( \pm 0,00)$ & $0,00( \pm 0,00)$ & 1,000 \\
\hline
\end{tabular}

† Data dinyatakan dalam Mean (+SD); *Data dinyatakan dalam persen

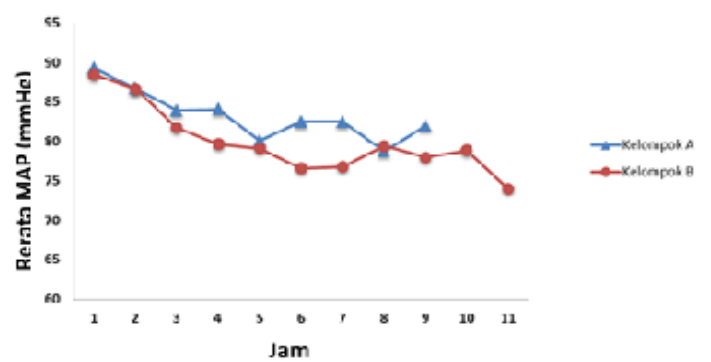

Gambar 2. Rerata Mean Arterial Pressure (MAP) Intraoperatif

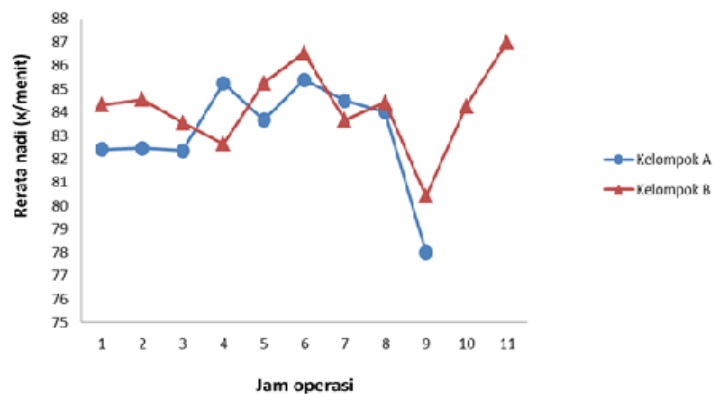

Gambar 3. Rerata Nadi Intraoperatif

\section{Pembahasan}

Penelitian ini membandingkan dua kelompok perlakuan yaitu kelompok A yang mendapatkan asam traneksamat intravena $20 \mathrm{mg} / \mathrm{kg}$ berat

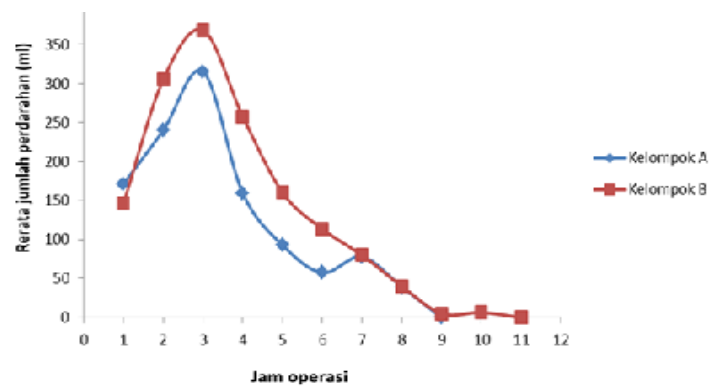

Gambar 4. Rerata Jumlah Perdarahan Intraoperatif Per Jam

badan sebelum insisi dengan kelompok $\mathrm{B}$ (kontrol) yang mendapatkan $\mathrm{NaCl}$ 0,9\% sebelum insisi. Pada penelitian ini tidak digunakan asam traneksamat secara kontinyu setelah pemberian pertama dengan alasan bahwa asam traneksamat dalam konsentrasi antifibrinolitik pada dosis 10$20 \mathrm{mg} / \mathrm{kg}$ berat badan dapat bertahan hingga 17 jam pada berbagai jaringan dan bertahan 7-8 jam pada serum. ${ }^{13}$ Parameter yang dibandingkan terutama jumlah perdarahan intraoperatif dan kebutuhan transfusi hingga 24 jam pasca operasi. Jumlah estimasi perdarahan pada kelompok A rata-rata 1008,51 $\pm 327,192 \mathrm{ml}$ dibandingkan pada kelompok B rata-rata $1347 \pm 539,120 \mathrm{ml}$ dengan nilai $p=0,021$, sehingga secara statistik dikatakan memiliki perbedaan yang bermakna $(p<0,05)$. Jumlah pasien yang mendapatkan transfusi 
intraoperatif pada kelompok A sejumlah 6 orang (30\%) dibandingkan sebanyak 15 orang $(75 \%)$ pada kelompok $B(p=0,004)$. Jumlah transfusi PRC intraoperatif yang diberikan pada kelompok A rata-rata $89,30 \pm 152,970 \mathrm{ml}$ dibandingkan pada kelompok B rata-rata $306,85 \pm 224,631 \mathrm{ml}$ $(\mathrm{p}=0,003)$ sehingga bermakna secara statistik $(\mathrm{p}<0,05)$. Jumlah pasien yang mendapatkan transfusi dalam rentang waktu 24 jam pasca operasi pada kelompok A sebanyak 6 orang (30\%) dan sejumlah 13 orang $(65 \%)$ pada kelompok B $(\mathrm{p}=0,027)$. Jumlah transfusi PRC dalam 24 jam pasca operasi yang diberikan pada kelompok A rata-rata $88,50 \pm 153,014 \mathrm{ml}$ dan pada kelompok $\mathrm{B}$ rata-rata $212,00 \pm 212,505 \mathrm{ml}$ (nilai $\mathrm{P} 0,028$ ), sehingga berbeda signifikan secara statistik $(p<0,05)$. Hal ini sesuai dengan penelitian di Arab Saudi tahun 2015 terhadap pasien 100 pasien yang menjalani kraniotomi pengangkatan tumor otak membandingkan pemberian asam traneksamat $10 \mathrm{mg} / \mathrm{kg}$ bolus intravena diikuti 1 $\mathrm{mg} / \mathrm{kg} / \mathrm{jam}$ dengan plasebo. Hasil dari penelitian ini menunjukkan jumlah perdarahan yang secara signifikan lebih rendah pada kelompok asam traneksamat dibandingkan kelompok plasebo namun tidak didapatkan perbedaan jumlah kebutuhan transfusi. ${ }^{19}$ Namun penelitian ini tidak mengkhususkan pada jenis tumor tertentu, sedangkan jenis tumor otak yang memiliki risiko perdarahan yang tinggi adalah meningioma karena kaya akan vaskularisasi. ${ }^{2,5,20}$

Penelitian ini juga sejalan dengan penelitian di India tahun 2016 dilakukan terhadap 60 pasien yang menjalani kraniotomi pengangkatan tumor meningioma elektif membandingkan jumlah perdarahan intraoperatif dan kebutuhan transfusi antara kelompok yang diberikan asam traneksamat $20 \mathrm{mg} / \mathrm{kg}$ selama 20 menit sebelum insisi diikuti $1 \mathrm{mg} / \mathrm{kg} / \mathrm{jam}$ hingga selesai operasi dibandingkan dengan plasebo. Kelompok asam traneksamat secara signifikan lebih sedikit jumlah perdarahan intraoperatif dan kebutuhan transfusi dibandingkan kelompok kontrol. ${ }^{20}$ Hasil lain dari penelitian ini adalah perbandingan jumlah penggunaan cairan intraoperatif antara kedua kelompok. Median jumlah kristaloid yang digunakan pada kelompok A, lebih sedikit dibandingkankelompokB $(p=0,012)$.Lamaoperasi pada kelompok A lebih singkat dibandingkan kelompok kontrol $(\mathrm{p}=0,033)$. Lama anestesi pada kelompok A lebih singkat dibandingkan berbeda pula secara signifikan $(\mathrm{p}=0,040)$ dibandingkan dengan kelompok B. Pada kelompok A, ratarata kadar $\mathrm{Hb}$ pasca operasi lebih tinggi dari kelompok B $(\mathrm{p}=0,005)$. Kadar Ht pasca operasi pada kelompok A lebih tinggi dari kelompok B $(\mathrm{p}=0,024)$. Kadar Hb, Ht, trombosit, PT, INR dan aPTT 24 jam pasca operasi tidak terdapat perbedaan signifikan antara kedua kelompok.

\section{Simpulan}

Pemberian asam traneksamat intravena $20 \mathrm{mg} /$ $\mathrm{kg}$ berat badan yang dilakukan 30 menit sebelum insisi dapat mengurangi jumlah perdarahan intraoperatif dan jumlah kebutuhan transfusi intraoperatif dan kebutuhan transfusi dalam 24 jam pertama pasca operasi dibandingkan dengan kelompok kontrol.

\section{Daftar Pustaka}

1. Bruder NJ, Ravussin P, Schoettker. Supratentorial masses: anesthetic consideration. Dalam: Cottrell JE, Patel P, penyunting. Cottrell and Patel's Neuroanesthesia. Edisi ke-6. Philadelphia: Elsevier; 2017, 189-90.

2. Perkins A, Liu G. Primary brain tumors in adults: diagnosis and treatment. Am Fam Physician 2016;93(3):211-7.

3. Ostrom QT, Gittleman H, Liao P, Rouse C, Chen Y, Dowling J, dkk. CBTRUS statistical report: primary brain and central nervous system tumors diagnosed in the United States in 2007-2011. Neuro Oncol 2014;16 (suppl 4) :iv1-iv63

4. Inez M, Bisri DY, Adam A. Insidensi tumor supratentorial berdasarkan jenis dan letaknya di RSUP Dr. Hasan Sadikin tahun 2012-2013. Jurnal Neuroanestesi Indonesia. 2015;4(3): $157-61$.

5. Martin AJ, Cha S, Higashida RT, Cullen SP, 
Halbach V, Dowd CF dkk. Assessment of vasculature of meningiomas and the effects of embolization with intra-arterial MR perfusion imaging: a feasibility study. Am J Neuroradiol 2017;28:1771-7.

6. Saraf S, McCarthy BJ, Villano JL. Update on meningiomas. Oncologist 2011;16:1604-13.

7. Vagnerova K, Rusa R. Fluid Management During Craniotomy. Dalam . Dalam: Cottrell JE, Patel P, penyunting. Cottrell and Patel's Neuroanesthesia. Edisi ke-6. Philadelphia: Elsevier; 2007, 52-62.

8. Butterworth JF, Mackey DC, Wasnick JD Fluid management and blood component therapy. Dalam: Butterworth JF, Mackey DC, Wasnick JD, penyunting. Morgan and Mikhail's Clinical Anesthesiology. Edisi Ke6. New York: McGraw-Hill; 2013; 1161-76.

9. Kisilevsky A, Gelb AW, Bustillo M, Flexman AM. Anaemia and red blood cell transfusion in intracranial neurosurgery: a comprehensive review. Br J Anaest 2018;16:1-11.

10. Tate P. Blood. Dalam: Tate P. Seeley's Principles of Anatomy \& Physiology Edisi Ke-2. New York: McGraw-Hill; 2012; 475-8.

11. Mayeux J, Alwon K, Collins S, Hewer I. Tranexamic acid in anesthetic management of surgical procedures. AANA Journal 2016;84(3):201-9.

12. Tengborn L, Blomback M, Berntorp E. Tranexamic acid - an old drug still going strong and making a revival. Thromb Research 2015;135:231-42.

13. Carless P. 17th Expert Committee on the Selection and Use of Essential Medicines, World Health Organization. Proposal for the inclusion of tranexamic acid (antifibrinolytic -lysine analogue) in the WHO Model List of Essential Medicines [draft report]. Tersedia di http://www.who.int/ selection medicines/committees/expert/17/
application/TRANEXAMIC ACID.pdf. Dipublikasikan 25 November 2008. Diunduh 14 Agustus 2017.

14. Mebel D, Akagami R, Flexman AM. Use of tranexamic acid is associated with reduced blood product transfusion in complex skull base neurosurgical procedures: a retrospective cohort study. Anesth Analg 2016;122:503-8.

15. Seddighi A, Nikouei A, Seddighi AS, Zali A, Tabatabaei SM, Yourdkhani F, dkk. The role of tranexamic acid in prevention of hemorrhage in major spinal surgeries. Asian J Neurosurg 2017;12:501-5.

16. Nuttall GA, Gutierrez MC, Dewey JD. A preliminary study of a new tranexamic acid dosing schedule for cardiac surgery. $\mathrm{J}$ Cardiothorac Vasc Anesth. 2008;22(2):230-5.

17. Shakur H, Roberts I, Bautista R, Caballero J, Coats T, Dewan Y, dkk (CRASH-2 Trial Collaborators). Effects of tranexamic acid on death, vascular occlusive events, and blood transfusion in trauma patients with significant haemorrhage (CRASH-2): a randomised, placebo-controlled trial. Lancet. 2010;376 (9734):23-32.

18. Vel R, Udupi BP, Prakash MV, Adinarayanan S, Mishra S, Babu L. Effect of low dose tranexamic acid on intraoperative blood loss in neurosurgical patients. Saudi J Anaesth. 2015; 9(1): 42-8.

19. Hooda B, Chouhan RS, Rath GP, Bithal PK, Suri A, Lamsal R. Effect of tranexamic acid on intraoperative blood loss and transfusion requirements in patients undergoing excision of intracranial meningioma. Proceedings of the 50th Anniversary Annual Scientific Meeting of Neuroanaesthesia Society of Great Britain and Ireland; 7-8 Mei 2015. Manchester, United Kingdom. Elsevier; 2015.

20. Cutley JD, Johnson KW. Fluids. Dalam: Cutley JD, Johnson KW. Physics Edisi Ke-6. New Jersey: John Wiley \& Sons; 2012;110-11. 